\title{
The Paradox of Scottish Life Imprisonment
}

\author{
Dirk van Zyl Smit \\ Professor of Comparative and International Penal Law, University of \\ Nottingham, UK \\ dirk.van-zyl-smit@nottingham.ac.uk
}

\section{Katrina Morrison}

Lecturer in Criminology, Edinburgh Napier University, UK

K.Morrison@napier.ac.uk

\begin{abstract}
More people are serving life sentences in Scotland as a proportion of the national population than in any other country in Europe. Yet, in many respects, Scotland claims to adopt a welfarist rather than a penal approach to criminal justice. This paper uses a wide range of data to explain the factors underpinning this paradox. It focuses on key aspects of the imposition and implementation of life sentences, providing, for the first time, an analysis that goes behind headline figures. The paper concludes that, notwithstanding the commitment to welfare in penal policy, the high rate of life imprisonment is driven by both increased punitiveness and attempts to reduce the risk that serious crime poses to society. Finally, the paper outlines strategies for reducing the use of life imprisonment, which may be more effective because they pay close attention to the Scottish penal context, but which have relevance for other jurisdictions seeking to reverse penal excess.
\end{abstract}

\section{Keywords}

life imprisonment - Scotland - sentencing - penal reform - Orders for Lifelong Restriction 
Scotland regards itself as progressive in many aspects of criminal justice. Paradoxically, by European standards it has an extraordinarily high rate of life imprisonment. What can explain the high numbers of prisoners serving life sentences in Scotland?

To provide some context to this question, we begin by reflecting on what is meant by life imprisonment, as it manifests itself in Scotland. We also compare life imprisonment in Scotland to that in other countries, particularly European countries that in other respects are not significantly different from Scotland.

The method adopted in this paper is not primarily comparative. Instead, the answer to the question about the high rates of life imprisonment in Scotland is sought, in the first instance, by examining closely the immediate determinants of the number of prisoners serving sentences of imprisonment that is, sentencing and release policies and practices. In so doing, it provides an original analysis of the drivers behind the headline figures.

In this regard, we focus first on murder, as the majority of Scottish life prisoners are serving life sentences for murder. We highlight the wide definition of murder and the mandatory nature of the life sentences that follow a conviction for murder, as well as the growing length of the minimum terms that all prisoners sentenced to mandatory life imprisonment must serve before they can even be considered for release. Discretionary life sentencing, which in modern Scotland mostly takes the form of Orders for Lifelong Restriction (OLRs), is also examined as a further aspect of Scottish sentencing practice contributing to the growing number of life prisoners.

Release policies and practices are considered separately, and attention is focused on the growing reluctance to release prisoners serving both mandatory and discretionary life sentences. To this factor we add the increased readiness to recall life prisoners to prison for breaching the conditions of their release.

These immediate drivers are then placed in the wider context of Scottish penal policy that emphasises welfare as well as retribution. We conclude that, while punitiveness plays a role in the growing number of prisoners serving life sentences in Scotland, a concern with public protection, coalescing around the management of risk, is also important. The rise in life imprisonment is being shaped by practical policy choices.

In the final section, we consider what can be done to reduce the number of life prisoners in a society such as Scotland which otherwise seeks to emphasise welfare and progressive approaches to justice. Our conclusion is that changing the immediate determinants of the high life imprisonment numbers is what is 
required to reduce the use of life imprisonment in Scotland and bring it into alignment with European norms. Such a strategy could also be applied by other jurisdictions seeking to reduce their prison populations.

\section{Life Imprisonment in Scotland}

Life imprisonment can be defined as 'a sentence, following a criminal conviction, which gives the state the power to detain a person in prison for life, that is, until they die there.' ${ }^{1}$ There are different types of life sentences throughout the world, but they fall into two broad categories: life without the possibility of parole and life with the possibility of parole.

In Scotland, all life prisoners have a prospect of parole; there is no sentence to life without parole. When imposing any life sentence, a Scottish judge must set a minimum term to be served in custody (described in law and in practice in Scotland as the 'punishment part'). After serving the punishment part, the prisoner is eligible for release by the Parole Board for Scotland. When life prisoners are released, they are subject to conditions of licence in the community for the rest of their lives. Breach of these conditions may lead to a return to custody.

In law, discretionary life sentences may be imposed by courts in Scotland for a wide range of offences other than murder. Historically, such sentences were simply called sentences of life imprisonment and not differentiated from mandatory life sentences, except that courts had a wide discretion on whether or not to impose them. However, since 2003, they have been replaced in practice by Orders for Lifelong Restriction (OLRs), which are also included in the overall official figures on Scottish life imprisonment. ${ }^{2}$ Accordingly this analysis focusses largely on OLRs and not on traditional discretionary life sentences, even though the latter still exist in Scots law and some prisoners may still be serving them.

OLRs, like the traditional discretionary life sentences are also imposed after conviction for serious violent or sexual offences other than murder. However, as explained more fully below, the decision on whether to impose these orders is a more complex process than that adopted for traditional discretionary

1 D. van Zyl Smit and C. Appleton, Life Imprisonment A Global Human Rights Analysis (Cambridge Mass.: Harvard University Press 2019) p. 35. This paper focuses on formal life sentences and does not discuss informal life sentences, which Van Zyl Smit and Appleton include in their definition.

2 Y. Gailey, L. Martin, and R. Webb, “An Exceptional Sentence” Exploring the Implementation of the Order for Lifelong Restriction', in K. McCartan and H. Kemshall, eds., Contemporary Sex Offender Risk Management, Volume I (Palgrave Macmillan, Cham, 2017) pp. 115-143. 
TABLE 1 Life Sentenced and OLR prisoners in custody per year

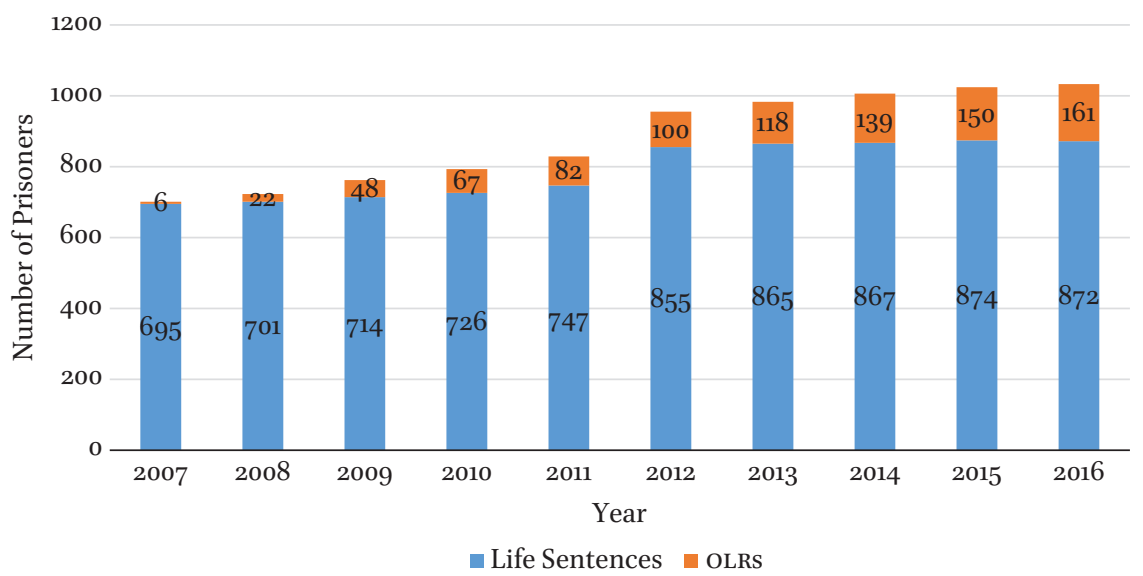

Source: Figures for total life sentences (including those recalled to custody from license in the community) from 1st September each year, in the Annual Council of Europe SPACE I reports 2007 - 2016 (Council of Europe SPACE I - Council of Europe Annual Penal Statistics: Prison Populations, Surveys 2007 - 2016. Strasbourg: Council of Europe. Available http://wp.unil.ch/ space/space-i/annual-reports/. Figures for OLRs from the Risk Management Authority (reporting year March - March) personal communication. The "Life sentences" figures are mostly prisoners serving mandatory life sentences for murder but also include those who were sentenced to discretionary life sentences prior to the introduction of OLRs.

life sentences. In their implementation and decision-making about release, OLRs follow the same pattern as other Scottish life sentences.

Table 1 shows the growing number of people serving life sentences of all kinds in Scotland. The significance of these figures will become apparent as they are placed in a comparative context below.

\section{Scottish Life Imprisonment in European and International Comparative Contexts}

Life imprisonment is the ultimate penalty in most European countries. ${ }^{3}$ Exceptions are Belarus, which retains the death penalty, and Andorra, Bosnia and Herzegovina, Croatia, Montenegro, Norway, Portugal, and the Vatican, where

3 European countries refer to all the countries in geographical Europe. These are the member states of the Council of Europe and Belarus, which is not a member state of the Council of Europe. 


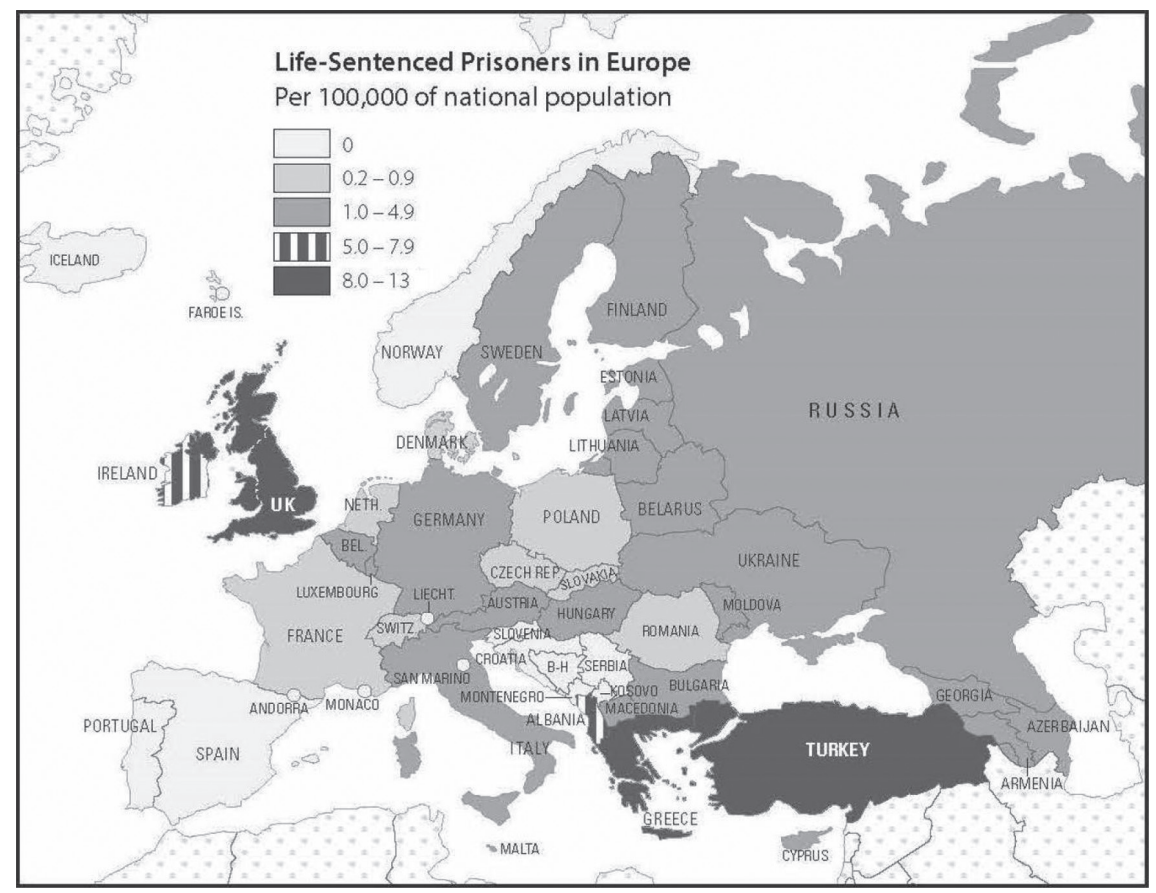

FIGURE 1 Life-sentenced prisoners in Europe 2016

Source: Adapted from Van Zyl Smit and Appleton, op. cit., p. 91.

the maximum sentence is a fixed term penalty. ${ }^{4}$ Within Europe, the United Kingdom has the highest rate of life imprisonment per hundred thousand of national population, while within the United Kingdom the rate in Scotland is slightly higher than that in England and Wales and in Northern Ireland. ${ }^{5}$

As Figure 1 shows, in 2016 only five European countries had a rate of more than 5 life prisoners per 100,000 of the national population: These were Albania 5.5, Greece 8.3, Ireland 7.4, Turkey 9.2 and the United Kingdom 13.0. At that stage, the UK together with Turkey (which has the second most) had more than half of life prisoners in Europe, that is, more than Russia, Germany, and every other European country combined.

If one focuses on Scotland as a separate jurisdiction, it had the highest proportion of life prisoners per 100,000 of national population in Europe. The 1038

4 D. van Zyl Smit and C. Appleton, op. cit.

5 SPACE I - Council of Europe Annual Penal Statistics: Prison Populations, Surveys 2016. (Strasbourg: Council of Europe, 2018) Table 7. All European figures in this paragraph are from that source. Note that figures in Table 7 for Scotland include OLRs, while the figures for England and Wales do not include the similar indeterminate sentence of Imprisonment for Public Protection. 
life prisoners in Scotland reflected a rate of 19.2 prisoners per 100000 of the national population. The equivalent rate for England and Wales was 12.7, and for Northern Ireland it was 8.3. In even sharper contrast to Scotland, for Germany the rate was 2.3 and for France 0.7 per 100000 of national population. The percentage of life prisoners in the national prison population in Scotland is also the highest in Europe, bar none.

If one looks beyond Europe, the rate in the USA at 50.3 life prisoners per 100 000 of the national population was much higher than that in Scotland. ${ }^{6}$ The USA has the highest rate of life imprisonment per national population of any country in the world and the greatest number of life prisoners. However, when it comes to life prisoners as a percentage of the national prison population, Scotland had a higher percentage, $13.6 \%$, than the USA, $10.5 \%$.

\section{Criminal justice related factors influencing the high number of life prisoners}

As has been widely recognised, prison numbers are, in the first instance, products of policy choices and penal cultures. ${ }^{7}$ In analysing these policies and practices both in respect of the imposition of life imprisonment and release of prisoners serving life terms, we have paid attention to changes over time in Scotland. We have also drawn some comparisons between Scotland and other countries, particularly those that have similar underlying rates of serious crime that could attract life imprisonment.

\subsection{Sentencing}

In order to have an overview of admissions to prison for life imprisonment we have consolidated various forms of admission in Table 2, below.

From this overview it is clear that admissions of various kinds have been in overall decline. Clearly, admissions alone cannot be the driver of the increase in the number of prisoners serving life sentences in Scotland. Nevertheless, it is necessary to consider sentencing as a factor in the high number of persons serving life sentences, as other aspects of the sentencing process may be of particular significance.

6 A. Nellis, loc. cit.

7 See e.g., T. Lappi-Seppälä, 'Explaining Imprisonment in Europe', 8 European Journal of Criminology (2011) 303-328; M. Tonry 'Explanations of American punishment policies: A national history', 11 Punishment and Society (1993) 377-394. 
TABLE 2 Admissions to life imprisonment

\begin{tabular}{lcccc}
\hline Year & $\begin{array}{c}\text { Mandatory } \\
\text { life sentences }\end{array}$ & $\begin{array}{c}\text { Orders for } \\
\text { Lifelong } \\
\text { Restriction }\end{array}$ & $\begin{array}{c}\text { Recalls to } \\
\text { custody from } \\
\text { license in the } \\
\text { community }\end{array}$ & $\begin{array}{c}\text { Total } \\
\text { admissions }\end{array}$ \\
& & & 18 & 71 \\
$2007 / 08$ & 48 & 5 & 13 & 87 \\
$2008 /$ o9 & 58 & 16 & 20 & 93 \\
$2009 / 10$ & 46 & 27 & 16 & 83 \\
$2010 / 11$ & 43 & 24 & 12 & 79 \\
$2011 / 12$ & 52 & 15 & 16 & 83 \\
$2012 / 13$ & 49 & 18 & 15 & 79 \\
$2013 / 14$ & 46 & 18 & 14 & 68 \\
$2014 / 15$ & 32 & 22 & 23 & 62 \\
$2015 / 16$ & 27 & 12 & 18 & 59 \\
$2016 / 17$ & 30 & 11 & 16.5 & $75 \cdot 75$ \\
Average over & 43 & 17 & & \\
10 years & & & & \\
\hline
\end{tabular}

Sources: life sentences from the annual annual Scottish Government Criminal Proceedings Bulletins, Annual Reports 2007/8 - 2016/7. Online at: https://www2.gov.scot/Topics/Statistics/ Browse/Crime-Justice/PubCriminalProceedings, accessed November, 2019. Data for Orders for Lifelong Restriction from the Risk Management Authority (personal communication). Figures for recall (including both recalled and revoked licenses) from the Parole Board for Scotland, Annual Reports 2007/8 - 2016/17. Online at: http://www.scottishparoleboard.gov.uk/documents .asp, accessed November, 2019 .

\subsubsection{Mandatory Life Sentences for Murder}

As illustrated in Table 3, below, life sentences for murder make up the large majority, on average $71 \%$, of all life sentences imposed in Scotland over the past ten years. This is in spite of the fact that there has been a decline in the reported homicide rate in recent years. ${ }^{8}$ How these sentences are arrived

8 There has been a general downward trend in homicides since 2003/04, when there were just over 130 homicides per year, to 2015/16 - 2018/19, when there have been between 59 and 62 homicides per year. See Scottish Government (2019) 'Homicide in Scotland 2018-2019'. Available online: https://www.gov.scot/publications/homicide-scotland-2018-19/pages/3/, accessed November, 2019. 
TABLE 3 Life sentences for murder

\begin{tabular}{lc} 
Year & $\begin{array}{c}\text { Numbers of life sentences imposed } \\
\text { for murder (\% of the total number } \\
\text { of life sentences for all offences) }\end{array}$ \\
\hline $2007 / 08$ & $45(85 \%)$ \\
$2008 / 09$ & $58(82 \%)$ \\
$2009 / 10$ & $45(62 \%)$ \\
$2010 / 11$ & $43(64 \%)$ \\
$2011 / 12$ & $52(78 \%)$ \\
$2012 / 13$ & $47(70 \%)$ \\
$2013 / 14$ & $46(72 \%)$ \\
$2014 / 15$ & $31(57 \%)$ \\
$2015 / 16$ & $27(69 \%)$ \\
$2016 / 17$ & $30(73 \%)$ \\
Average over 10 years & $71 \%$ \\
\hline
\end{tabular}

Source: Annual Scottish Government Criminal Proceedings Bulletin, 2007/8 - 2016/7 (Scottish Government, 2009 - 2018) loc. cit.

at and what they imply for the length of time that sentenced murderer is likely to serve is therefore a factor that may influence the prevalence of life imprisonment.

In Scotland, there is a legal requirement that a life sentence be imposed following a murder conviction. In practice, the heinousness of the crimes that are found to constitute murder varies enormously. International comparative research suggests that, where courts have a discretion on whether or not to impose life imprisonment for murder, they often elect not to impose a life sentences. ${ }^{9}$

Mandatory life imprisonment is relatively unusual in Europe, where only Scotland, the other jurisdictions of the United Kingdom, Ireland and Germany have provision for such sentences. As we have seen, the United Kingdom and Ireland have some of the highest rates of life imprisonment, relative to their national populations, in Europe. The rate in Germany is not as high as that in the United Kingdom and Ireland but this may result from their definitions of murder.

9 D. van Zyl Smit and C. Appleton, op. cit. 
4.1.2 Definition of murder

Murder is a Scots common law crime and defined broadly. Murder is a willful act that causes the destruction of life, whether wickedly intended to kill, or displaying such wicked recklessness as to imply a disposition depraved enough to be regardless of consequences. ${ }^{10}$ When death results from any serious and dangerous crime, murder may have been committed, even though the specific intent to kill is absent. ${ }^{11}$ This definition is similar to those in England Wales and Ireland, where there are also mandatory life sentences.

Several European countries have narrower definitions of murder than Scotland and much lower numbers of life prisoners. However, one cannot attribute these lower numbers to the restrictive definitions, as the life sentences for murder are discretionary in most of them and the courts relatively rarely impose life imprisonment for murder. ${ }^{12}$

Germany, however, is another European country that has mandatory life imprisonment and a similar homicide rate to Scotland. A comparison with it is therefore possible. The definition of murder in Germany is significantly more restrictive than that in Scotland:

The murderer ... is any person who kills a person for pleasure, for sexual gratification, out of greed or otherwise base motives, by stealth or cruelly or by means that pose a danger to the public or in order to facilitate or to cover up another offence. ${ }^{13}$

All other forms of deliberate killing in Germany are classified as manslaughter, which does not carry a mandatory sentence of life imprisonment and

\footnotetext{
10 Drury v. H.M. Advocate, 2001 S.L.T. 1013.

11 J. Chalmers and F. Leverick eds. Criminal Law of Scotland, part 2, $4^{\text {th }}$ edition (London: Sweet and Maxwell, 2016) ch. 30. Murder is also defined broadly in England and Wales (D. Ormerod and D. Perry, eds., Blackstone's Criminal Practice (Oxford: Oxford University Press, 2019) B 1.1-14) and in other jurisdictions, including Northern Ireland and the Republic of Ireland, that follow English common law in this regard. As noted in the comparative section above, the imprisonment rates in these jurisdictions, which all have mandatory life sentences for murder, are also amongst the highest in Europe.

12 An extreme example is the Netherlands, where Article 289 of the Penal Code provides that '[a]ny person who intentionally and with premeditation takes the life of another person shall be guilty of murder'. Persons convicted of murder may be sentenced to life imprisonment but in practice courts very rarely do so. The result is that prisoners sentenced to life imprisonment make up only .2 per 100 oo of the national population. For details see W. van Hattum and S. Meijer 'An administrative Procedure for Life Prisoners', in D. van Zyl Smit and C. Appleton eds., Life Imprisonment and Human Rights (Oxford: Hart, 2016) 141-165. Art 211(2) of the German Criminal Code (translated by M. Bohlander).
} 
life sentences very rarely imposed..$^{14}$ Given the definitional differences, it is not surprising that the number of persons convicted of murder in Scotland relative to the size of the population in 2016 was two and a half times that in Germany. ${ }^{15}$ Given the major role that life imprisonment for murder plays in overall life imprisonment numbers in both countries, this simple definitional difference is a key factor in explaining the significant difference in their life imprisonment rate.

$4 \cdot 1.3$

The impact of minimum terms: the punishment part of life sentence

Sentencers in Scotland have both the power and duty to determine the time an individual must spend in custody before they are eligible for consideration for release. These minimum custodial periods, the punishment part, have been growing gradually longer.

Section 1 of the 2001 Convention Rights (Compliance) (Scotland) Act provides that the sentencer must specify this period 'in years and months'. This provision eliminates the possibility of a 'whole life order' of the kind that can be imposed in England and Wales. Such whole life orders exclude routine consideration of release in particularly serious cases where a minimum period is deemed to be an insufficient punishment.

A further difference from England and Wales is that in the Scottish legislation there is no specific legislative guidance on how judges should exercise their discretion in setting a punishment period. ${ }^{16}$ As its title suggests, the 2001 Convention Rights (Compliance) (Scotland) Act was an attempt to bring Scots law in line with the European Convention on Human Rights, because the European Court of Human Rights was beginning to interpret life sentences from which there is no prospect of release as inherently inhuman and degrading. ${ }^{17}$

14 A. Dessecker, 'Constitutional Limits on Life imprisonment and Post-Sentence Preventive Detention in Germany', in D. van Zyl Smit and C. Appleton, eds., loc. cit., pp. 411-434.

15 This ratio was calculated on the basis that in 2016 there were 27 convictions for murder in Scotland (Scottish Government Criminal Proceedings Bulletin 2016/17 loc cit.) and 164 in Germany (Statistisches Bundesamt (Strafverfolgung - Fachserie 10 Reihe 3- 2016 (Berlin: Destatis, 2017) p. 24). Using the 2016 national population figures from SPACE 1, loc. cit., the respective ratios of murder convictions per 100,000 of national population were .5 for Scotland and .2 for Germany.

16 J. Bild, The mandatory life sentence for murder: lessons from two neighbours. (Unpublished $\mathrm{PhD}$, University of Cambridge, 2014).

17 Sawoniuk v.UK, ECtHR (app. no. 63716/oo,) 29 May 2001; Einhorn v. France ECtHR (app. no. 71555/01), 12 July 2001, §§ 27-28; Nivette v. France ECtHR (app. no. 4419o/98) 3 July 2001; Weeks v. UKUK, EComHR (app. no. 9787/82) 7 December 1984, § 72; Kotälla v. the Netherlands, (app. no. 7994/77), 6 May 1978, p. 238. 
TABLE 4 Punishment parts of life sentences for murder

Year

Average punishment part for

life sentences for murder

\begin{tabular}{ll}
\hline $2007 / 08$ & 14.6 \\
$2008 / 09$ & 16.3 \\
$2009 / 10$ & 15.4 \\
$2010 / 11$ & 17.5 \\
$2011 / 10$ & 16.8 \\
$2012 / 13$ & 17.4 \\
$2013 / 14$ & 18.0 \\
$2014 / 15^{\mathrm{a}}$ & 19.2 \\
$2015 / 16$ & 18.9 \\
$2016 / 17$ & 19.1 \\
\hline
\end{tabular}

ancludes one discretionary life sentence imposed for an offence other than murder.

Source: J. Bild, op. cit.; unpublished analysis by the Scottish

Government Justice Analytical Services

The wide discretion that the 2001 Act gave sentencers in determining the punishment part of life sentences was initially seen as a progressive development. In the first years after its enactment, this power was used in a relatively restrained way, with average minimum terms hovering at around 14 years between 2001 and 2006. ${ }^{18}$ However, as Table 4 shows, from 2007 onwards these terms began to grow. In 2007/08, average length for a life sentence was 14.6 years, but by $2016 / 17$ it was 19.1 years, an increase of $31 \%$ over this period.

In the absence of guidelines, Scottish courts have contributed to this development through changes in their case law that reflect a more punitive attitude to the punishment of murder in particular. Initially, courts adopted a selfrestraining policy for the punishment part of a life sentence for murder: 12 years as the starting point; 'in the region of 20 years' as the norm when there was some aggravating factor; and 30 years as the de facto maximum for the punishment part of the sentence. ${ }^{19}$ In 2009, however, the Appeal Court largely abandoned these restraints: 12 years was declared suitable only where a 'strong

\footnotetext{
18 J. Bild, op. cit.

19 Walker v. H.M. Advocate, 2003 S.L.T. 130.
} 
mitigatory circumstances' existed and the maximum punishment term of 30 years was scrapped. ${ }^{20}$

The more punitive attitude of Scottish courts is illustrated in the minimum term set in the 2014 case of H.M. Advocate v. Sinclair. In his sentencing statement, the judge correctly told the man facing the life sentence that he had:

to designate a period which must pass before you can apply to be released on licence. The purpose of that period, known as the punishment part of the sentence, is to satisfy the requirements of retribution and deterrence. Whether you are ever released thereafter will not be a matter for me but for the Parole Board. ${ }^{21}$

However, the judge immediately added sarcastically, 'although I intend to make matters easier for [the Parole Board].'22 The sentencing judge then set a minimum period of 37 years, which meant that the individual would be over a hundred years old before the Parole Board could consider his release. Although the statute allowed the judge to impose a minimum term, this ensured that in practice the prisoner had no realistic prospect of release, while a clear requirement of the jurisprudence of the European Court of Human Rights (ECtHR) is that the prospect of release must not only exist in law but also in fact. ${ }^{23}$

There are worrying signs that this punitive approach is gaining support outside the judiciary too. Although Scots laws does not allow whole life sentences, that is, sentences where the punishment part is not set in terms of a minimum number of years but is incarceration for the rest of the prisoner's life, there are members of the Scottish Parliament who argue that the introduction of such sentences would be a desirable development. ${ }^{24}$ Interestingly enough,

$20 \quad$ H.M. Advocate v. Boyle [2009] HCJAC 89.

21 H.M. Advocate v. Sinclair, Reported at http://www.scotland-judiciary.org.uk/8/1338/HMAv-ANGUS-SINCLAIR, accessed November, 2019.

22 Ibid.

23 Vinter and Others v.UK, ECtHR (apps. 66069/og, 130/10 and 3896/10), 9 July 2013 [GC]; Murray v. The Netherlands, ECtHR (app. 10511/10), 26 April 2016 [GC]; M. Rogan, 'Discerning Penal Values and Judicial Decision Making: The Case of Whole Life Sentencing in Europe and the United States of America' 57 The Howard Journal of Crime and Justice (2018) 321-338.

24 Scottish Parliament Whole Life Sentences Debate. Scottish Parliament Official Report $4^{\text {th }}$ June, 2019. Available online: http://www.parliament.scot/parliamentarybusiness/report .aspx? $r=12155 \& \mathrm{i}=109832$, accessed November, 2019. See also Proposed Whole Life Custody (Scotland) Bill, available online: https://www.parliament.scot/parliamentarybusiness/ Bills/11685.aspxhttps://www.parliament.scot/parliamentarybusiness/Bills/111685.aspxaccessed November, 2019 . 
the opponents of the introduction of whole life sentences argued that the current law already allowed de facto whole life sentences and quoted the example of the 37-year minimum period in H.M. Advocatev. Sinclair discussed above. They also regarded the fact that prisoners serving OLRs are very rarely released (see below), as a further indication that life imprisonment in Scotland is already appropriately severe. Although hubristic parliamentary exchanges do not equate to scrutinised legislation, it is alarming that there are those within the Scottish polity who raise the possibility of dignity-destroying whole life sentences, particularly at a time when they are being phased out in the rest of Europe.

Even if whole life orders are not imposed in Scotland, the danger remains that the length of the punishment parts of life sentences for murder will continue to grow, thus driving up the time that those serving these sentences are likely to spend in prison before being considered for release. This aspect of the life sentences for murder is an important driver of the continued growth of the number of people serving life sentences, even in the absence of increasing number of life sentences being imposed.

\subsubsection{Discretionary Life: Orders for Lifelong Restriction}

The second type of life sentence in Scotland is a discretionary life sentence, which generally takes the form of an Order for Lifelong Restriction (OLR). Table 1 shows that prisoners serving OLRs are a growing part of the total number of Scottish life prisoners. OLRs are sentences passed by the court on persons who are convicted of serious violent or sexual offences, not murder, and deemed to pose a high future risk of reoffending. The key determinant in deciding whether to impose an OLR, rather than a fixed-term sentence proportionate to the offence, is the risk that prisoners may pose if they return to society. If the prosecutor or judge assesses that certain risk criteria may be met following conviction, they are required to seek a standardised and thorough risk assessment via a Risk Assessment Order and subsequent Risk Assessment Report, which are written by accredited risk assessors. The criteria of risk are that:

the nature of, or the circumstances of the commission of, the offence of which the convicted person has been found guilty either in themselves or as part of a pattern of behavior are such as to demonstrate that there is a likelihood that he, if at liberty, will seriously endanger the lives, or physical or psychological well-being, of members of the public at large. ${ }^{25}$

25 Section 210 E of the Criminal Justice (Scotland) Act 2003. 
Following consideration of the Risk Assessment Report, the sentencing judge is able to decide whether, on the balance of probability, the risk criteria outlined in the Act have been met and whether an OLR should be imposed.

When imposing an OLR, the judge must set a punishment part of the sentence in the same way as for life prisoners. After this minimum custodial period has elapsed, prisoners sentenced to OLRs are eligible to be considered for release on licence by the Parole Board. Following release, the individuals are subject to intense supervision in the community and subject to a Risk Management Plan for the rest of their lives. ${ }^{26}$

OLRS were introduced in 2003 on the recommendation of the MacLean Committee, which had been established in 1999 following a high-profile case in which an individual was released from a secure hospital due to a loophole in the detention of individuals who were considered to pose a high risk, but who were not deemed 'treatable'.27 The MacLean Committee argued that, for a 'small number of individuals', it would be appropriate to introduce a new sentence that combined the seriousness of their offence with the nature of risk they themselves posed, and to subject such disposals to rigorous risk assessment. $^{28}$

The criteria for imposing OLRs are noteworthy for two reasons. First, the index offence triggering an OLR is not necessarily a serious violent or sexual offence, because the legislation includes consideration of offences 'which, or the circumstances of the commission of which, are such that it appears to the Court that the person has a propensity to commit any of the [prescribed sexual, violent or life endangering] offences'. ${ }^{29}$ This creates a risk of widening the net for OLRs to be used for relatively minor offences, as well as very serious ones, if there is a potential future risk..$^{30}$

Second, what sets OLRs apart from other sentences is that the risk assessment processes, upon which they are based, may draw not only on previous

26 Y. Gailey et al. loc. cit.

27 J. Vess, 'Forensic risk assessment: Public protection versus offender rights', in M. Nash and A. Williams, eds., Handbook of Public Protection. (Cullompton: Willan, 2010) pp. 87-102.

28 The MacLean Report. Report of the Committee on Serious Violent and Sexual Offenders (The MacLean Report). Edinburgh: The Scottish Executive, 2002. p. 17.

29 Y. Gailey et al., loc. cit., p. 118.

30 For example, in 2017/18, one OLR sentence was passed for the main offence of 'fire-raising' (Scottish Government (2019) Criminal Proceedings Bulletin, available online: https:// www.gov.scot/publications/criminal-proceedings-scotland-2017-18/, accessed November, 2019). Wilful fire-raising is the 'definitive intention to set fire to the property' without the intention of harming individuals (Scottish Crime Recording Standards, available online: https://www.scotland.police.uk/assets/pdf/138327/232757/scottish-crime-recordingstandard-new, accessed November, 2019). 
convictions but also on previous allegations that resulted in an acquittal at trial. ${ }^{31}$ Even though the Risk Assessment Report must discuss the extent to which its final recommendations rely on these factors, the fact that unproven allegations can influence future sentences at all is alarming. ${ }^{32}$

Although OLRs were intended for a small number of cases, they were initially used quite freely, peaking with 27 OLR sentences imposed in 2009 (see Table 2 above). Since then, new legislation and appellate rulings seem to have prevented further upwards drift in the number of oLRs imposed. ${ }^{33}$ Moreover, the minimum custodial parts of the OLR sentences are relatively short, since 2007/08 the average length has never exceeded six years.

These relatively short punishment parts reflect the reality that, from the perspective of punishment alone, the index offences triggering these sentences were relatively much less serious than murder. Whether this means that in practice prisoners subject to OLRs will be in prison only for relatively short terms, is considered in the context of release on parole in the next section.

TABLE 5 Punishment parts of OLR sentences

\begin{tabular}{lc}
\hline Year & Average punishment part for OLRS \\
\hline $2007 / 08$ & 8.25 \\
$2008 / 09$ & 4.93 \\
$2009 / 10$ & 4.9 \\
$2010 / 11$ & 4.42 \\
$2011 / 10$ & 4.60 \\
$2012 / 13$ & 3.67 \\
$2013 / 14$ & 3.51 \\
$2014 / 15$ & 5.57 \\
$2015 / 16$ & 5.93 \\
$2016 / 17$ & 5.97 \\
\hline
\end{tabular}

Source: Risk Management Authority (personal communication).

31 Y. Gailey et al., loc. cit.

32 As Von Hirsch argues, previous, but unproven, allegations should play no role in sentencing: A. von Hirsch, 'Desert and previous convictions in sentencing' 65 Minnesota Law Review (1980) 591.

33 Y. Gailey et al., loc. cit. 


\subsection{Release}

The release of life prisoners in Scotland does not happen automatically once they have served the punishment part, that is, the minimum custodial portion of their sentences. However, at any time after life prisoners have completed the punishment part, the Parole Board for Scotland may order their conditional release from custody.

\subsubsection{Release/Parole}

The Parole Board makes its release decision according to the test that custody is 'no longer necessary for the protection of the public from serious harm.'34 The Board relies fundamentally on the actions and decisions of others in the system, including materials made available in the dossiers that are prepared for its consideration, meaning that there are a number of other gate-keepers who can prevent or delay a prisoner's progress towards release. ${ }^{35}$ Many prison officers, psychologists and probation officers make important decisions throughout the prisoners' sentences and their reports are included in the dossiers. Parole Board decisions are therefore influenced by the quality of the recording of earlier decisions, and the opportunities that the prisoner has had in custody to demonstrate their low risk following release.

One important factor affecting the decisions of the Parole Board is the opportunity for progression that life prisoners have during the course of their long sentences, including access to suitable rehabilitation programmes in prison conducted in 'open estate' conditions. Decisions on release are therefore affected by the ability of the Scottish Prison Service to manage progression. Recent inspectorate reports have highlighted progression as an area of concern, with long waiting lists for rehabilitative programmes, which a 'substantial number' of prisoners are unable to complete in order to be eligible for consideration for release. ${ }^{36}$ These reports draw attention to the extent to which prisoners' release is contingent on the capacity of the system to offer them opportunities to 'rehabilitate' themselves and for this to be demonstrated. A related issue for those prisoners serving OLRs with short punishment parts (four years or less), is that they may not be able to demonstrate an acceptably

34 Parole Board for Scotland Role of the Board. Available online: http://www.scottishpa roleboard.gov.uk/page/role_of_the_board, accessed November, 2019.

35 J. Lackenby, 'To Parole or Not to Parole? How do Parole Board Members make decisions about Parole?', 237 Prison Service Journal (2018) 32-35.

36 Her Majesty's Chief Inspectorate of Prisons for Scotland, Annual Report 2017-2018. Available online: https://www.prisonsinspectoratescotland.gov.uk/publications/hm-chiefinspector-prisons-scotland-annual-report-2017-2018, accessed November, 2019. 
TABLE 6 Parole Board decisions on life prisoners

\begin{tabular}{lcccccc}
\hline Year & $\begin{array}{c}\text { Life prisoner } \\
\text { cases } \\
\text { referred for } \\
\text { consideration }\end{array}$ & $\begin{array}{c}\text { Numbers } \\
\text { where } \\
\text { release } \\
\text { directed }\end{array}$ & $\begin{array}{c}\text { Numbers not } \\
\text { recommended } \\
\text { for release }\end{array}$ & $\begin{array}{c}\text { Numbers } \\
\text { of cases } \\
\text { postponed } \\
\text { or adjourned }\end{array}$ & $\begin{array}{c}\text { Number } \\
\text { who } \\
\text { received } \\
\text { a further } \\
\text { sentence }\end{array}$ & $\begin{array}{c}\text { Number of } \\
\text { cases not yet } \\
\text { referred to } \\
\text { Tribunal } \\
\text { withdrawn }\end{array}$ \\
\hline $2007 / 08$ & 324 & $75(23 \%)$ & $189(58 \%)$ & $52(16 \%)$ & - & - \\
$2008 / 09$ & 279 & $52(19 \%)$ & $157(56 \%)$ & $61(22 \%)$ & $7(3 \%)$ & - \\
$2009 / 10$ & 243 & $55(23 \%)$ & $135(56 \%)$ & $44(18 \%)$ & $7(3 \%)$ & - \\
$2010 / 11$ & 262 & $48(18 \%)$ & $173(66 \%)$ & $59(23 \%)$ & $4(2 \%)$ & $37(14 \%)$ \\
$2011 / 12$ & 241 & $43(18 \%)$ & $146(61 \%)$ & $43(18 \%)$ & $2(1 \%)$ & $11(5 \%)$ \\
$2012 / 13$ & 231 & $40(17 \%)$ & $148(64 \%)$ & $31(13 \%)$ & $4(2 \%)$ & $8(3 \%)$ \\
$2013 / 14$ & 356 & $56(16 \%)$ & $187(52 \%)$ & $67(19 \%)$ & $9(3 \%)$ & $37(10 \%)$ \\
$2014 / 15$ & 320 & $68(21 \%)$ & $159(50 \%)$ & $56(18 \%)$ & $4(1 \%)$ & $33(10 \%)$ \\
$2015 / 16$ & 366 & $44(12 \%)$ & $195(53 \%)$ & $114(31 \%)$ & - & $13(4 \%)$ \\
$2016 / 17$ & 375 & $46(12 \%)$ & $207(56 \%)$ & $106(28 \%)$ & - & $16(4 \%)$ \\
\hline
\end{tabular}

Source: Parole Board for Scotland Annual Reports 2007/8 - 2016/17 (Parole Board for Scotland $2009-2018$ ) and personal communication. The Parole Board for Scotland note that a possible reason why total numbers of cases do not add to $100 \%$ in all cases is because of a change in counting practices from 'prisoners' to 'cases' within the earlier time-frame analyzed (personal communication)

low level of risk at the point of consideration for release, because the Prison Service was unable to respond to the 'complexity of [their] risk and needs' within their time in custody. ${ }^{37}$

As illustrated in Table 6, the rate of release of life prisoners by the Parole Board has never exceeded a quarter of those who qualify for consideration: that is, those prisoners who had served the punishment part of their sentences and were being considered for release for the first time or subsequently. For the last two years of statistics available in our analysis, only $12 \%$ of those considered have been released. A reason for the recent decline in releases has been an increase in numbers of cases adjourned as part heard or postponed without being heard, indicating problems around efficiency and management in the system. 
TABLE 7 OLR sentenced prisoners released by the Parole Board

Year

Numbers referred to the Numbers where release directed Board for consideration ( $\%$ of cases considered)

\begin{tabular}{lcl}
\hline $2007 / 08$ & - & - \\
$2008 / 09$ & - & - \\
$2009 / 10$ & - & - \\
$2010 / 11$ & - & - \\
$2011 / 10$ & 13 & 0 \\
$2012 / 13$ & 6 & 0 \\
$2013 / 14$ & 36 & $1(3 \%)$ \\
$2014 / 15$ & 33 & $1(3 \%)$ \\
$2015 / 16$ & 52 & 0 \\
$2016 / 17$ & 64 & 0 \\
\hline
\end{tabular}

Source: Parole Board for Scotland Annual Reports 2007/8 - 2016/17 (Parole Board for Scotland $2009-2018$ loc. cit.)

Furthermore, our analysis shows that the Parole Board is even more reluctant to release OLR sentenced prisoners at the first possible opportunity, that is, at the end of their punishment parts.

From the imposition of the first OLRs in 2000 until 2017, only two prisoners serving this sentence have been released by the Parole Board, following the relatively short custodial portion of the court-imposed sentence. The reluctance to parole prisoners serving OLRs explains their increased proportion of overall life prisoner population (Table 1 above) absent an increase in the number of oLRs imposed (Table 2 above), or the length of the custodial portion of these sentences (Table 5 above). Taken together, the figures on the release of life prisoners, and particularly those serving OLRs, reveal that the length of punishment parts of their sentences has very little bearing on the length of time they actually serve.

\subsubsection{Release Conditions}

The Parole Board also has responsibility for establishing the licence conditions for release into the community. Conditions for all life prisoners include the 'standard' conditions, such as the requirement not to commit a further criminal offence, and to report any contact with the police to their supervising officer. More nebulously defined conditions, such as being 'of good behaviour 
and ... [keeping] the peace', are also standard conditions. ${ }^{38}$ Prisoners are subject to supervision from social workers, and must immediately notify their social worker if they are arrested or even questioned by the police. ${ }^{39}$ There may also be a number of specific individualized conditions. All these licence conditions impact the number of all life prisoners recalled to custody.

4.2.3 Recall to custody

A final reason for the high numbers of life prisoners in Scotland is the increase in life sentenced individuals being recalled to custody following a breach of their licence conditions. How the decision to recall is made is particularly important. In Scotland, individuals with life sentences remain subject to license conditions in the community for the rest of their lives. This is unlike former life prisoners in other jurisdictions, whose release conditions are time limited, and who therefore are subject to recall only for a limited number of years..$^{40}$ Persons released from life imprisonment in Scotland, however, are never fully at liberty.

As Table 1 shows, recalled life prisoners make up a large proportion of the admissions to prison every year. Over a ten-year period, the average number of new admissions to prison was 70 per year (this includes both life sentences and OLRs). In the same period, on average, there were 16.5 people per year who were returned to custody following a breach of their life license conditions. The already high numbers of life prisoners were increased by a further $27 \%$ through recalls to custody.

Recall is influenced by at least three institutional factors. The first factor relates to the licence conditions both standard and individual. Once life prisoners are released, they are bound by their licence conditions and are under the supervision of criminal justice professionals for the rest of their lives. Persons who have been sentenced to OLRs will also be subject to individual Risk Management Plans, which are multi-agency arrangements co-ordinated by their local authority. ${ }^{41}$ Licence conditions must be both 'specific and enforceable, ${ }^{42}$ and balance an assessment of risk and public protection with what the individual requires to support reintegration. However, those monitoring licences in Scotland, (for all sentence types, not only life sentences) consider some conditions set by the Parole Board, such as total bans on internet,

38 Parole Board for Scotland, Role of the Board, loc cit.

39 Parole Board for Scotland, Role of the Board, loc cit.

40 D. van Zyl Smit and C. Appleton, op. cit., ch. 10.

41 Y. Gailey et al, loc, cit.

42 Parole Board for Scotland, Role of the Board, loc cit. 
telephone and alcohol use, to be overly restrictive and potentially impossible to monitor. ${ }^{43}$

The second factor is the varying degree of discretion exercised by the supervising officers in reporting a suspected breach to the Parole Board for consideration of recall. They must report further alleged offending to the Board, on this matter, there is no discretion. On licence conditions other than not committing further criminal offences, supervising officers have, in theory, discretion over whether to refer. ${ }^{44}$ However, they are less likely to use their discretion in cases involving the risk of serious harm, because they are required to place public safety at the forefront of their consideration of such cases. ${ }^{45}$ The result is that supervising officers increasingly seek accountability outwards (to the public), rather than downwards (to the person under supervision). ${ }^{46}$

The third factor relates to decisions of the Parole Board when it is confronted by a breach of licence conditions. Over a ten-year period, on average, $37 \%$ of all cases involving life sentence prisoners resulted in a return to custody, as did $72 \%$ of all cases in which life licences had been revoked by Scottish Ministers (following concerns raised by the supervising officer). ${ }^{47}$

Whether these recall rates are justified is an open question. Recall should be used sparingly, for '[t]hose to whom [recall] applies have already served the period of imprisonment deemed sufficient as punishment, and have been assessed as posing no further risk to society. There should therefore be powerful, and challengeable reasons for re-detention. ${ }^{48}$ Existing research does not reveal whether levels of breaches resulting in a return to custody result from excessively onerous licence conditions, from the discretion exercised by supervising officers, or from the decisions of the Parole Board in each case. What is beyond doubt, however, is that, under the current system, life sentences impact the sentenced individuals long after they have served the custodial portion of their sentence. Weaver et al argue that the use of recall must be regarded

43 B. Weaver and M. Barry, 'Managing high risk offenders in the community: Compliance, cooperation and consent in a climate of concern' 6 European Journal of Probation (2014) 278-295.

44 B. Weaver, et al. 'The failure of recall to prison: Early release, front-door and back-door sentencing and the revolving prison door in Scotland' 4 European Journal of Probation (2012) 85-98.

Scottish Government. 'National Objectives for Social Work Services in the Criminal Justice System: Standards - Throughcare.' (2006). Available online: https://www2.gov.scot/ Publications/2004/12/20473/49301, accessed November, 2019.

46 B. Weaver, et al., loc. cit.

47 Parole Board for Scotland, Role of the Board, loc cit.

48 Justice, Sentenced to Life: Reform of the Law and Procedure for Those Sentenced to Life Imprisonment (London: Justice, 1996). p. 75 . 
as part of a wider logic of punishment rather than a separate technical issue. ${ }^{49}$ Given the consistently high numbers of people recalled to custody while on life licence in the community, there is no question that recall of life prisoners is an important part of the broader system of punishment in Scotland.

\section{The Scottish Penal Context}

So far, we have focused on the specific sentencing and release policies and practices that contribute collectively to the high number of life sentences currently being served in Scotland. However, they do not operate in a vacuum but in a wider Scottish context.

Scholars have argued that the Scottish penal policy is aligned with welfarism and the wider ideals of social justice. ${ }^{50}$ These ideals are expressed most acutely in juvenile justice, ${ }^{51}$ and in community justice services which remain firmly rooted within the practices and traditions of social work. ${ }^{52}$ In addition, Scotland's independent legal institutions and system have enabled it to sustain a unique 'criminal justice culture', 53 which is characterised by 'compassionate justice', albeit not without internal contradictions. ${ }^{54}$ The Scottish approach has allegedly opened space to consider a form of justice that is aligned with parsimony, ${ }^{55}$ and that diverges from the punitive polices followed in England. Indeed, it is claimed that one of Scotland's 'triumphs' that it has been able to

49 B. Weaver et al, loc. cit.

50 D. Garland, 'Preface' in P. Duff and N. Hutton, eds., Criminal Justice in Scotland (Aldershot: Ashgate, 1999) pp. xiii-xvi; L. McAra, 'Modelling Penal Transformation' 7 Punishment and Society (2005) 277-302; S. McVie, 'Social Order: Crime and Justice in Scotland' in D. McCrone, ed. The New Sociology of Scotland (London: Sage, 2017) pp. 293-322.

51 L. McAra, and S. McVie, 'The Scottish juvenile justice system: Policy and practice' in J. Winterdyke ed Juvenile Justice: International Perspectives, Models and Trends, (Boca Raton: Taylor and Francis, 2014) pp. 263-294.

$5^{2}$ F. McNeill, and B. Whyte, Reducing Reoffending: Social Work and Community Justice in Scotland (Cullompton: Willan, 2007).

53 P. Duff and N. Hutton, 'Introduction' in P. Duff and N. Hutton, eds., loc.cit., pp. 1 - 13.

54 L. McAra, 'Can Criminologists Change the World? Critical Reflections on the Politics, Performance and Effects of Criminal Justice' 57 British Journal of Criminology (2017) 767-788. In this paper, McAra discusses the disconnect between the 'political strategy', 'institutional performance' and 'embodied experience' of Scottish criminal justice.

55 F. McNeill, 'Determined to Punish? Scotland's Choice' in G. Hassan and R. Ilett, eds., Radical Scotland: Arguments for Self-Determination (Edinburgh: Luath Press, 2011) pp. 128-142. 
'staunchly adhere' to welfarist principles that are under threat from populist punitivism. ${ }^{56}$

The aspirations towards progressiveness in Scotland have tended, however, to focus more on those who have committed minor offences. There is far less compassion for those who have committed more serious crimes, and nor have there been calls for penal reform in this area. On the contrary, as we have shown, there is powerful tendency, among both the judiciary and politicians, to support life sentences that will result in prisoners remaining in prison for increasingly long periods.

Addressing Scotland's high overall rate of imprisonment has been on the political agenda under successive Scottish administrations. ${ }^{57}$ The current focus of penal reform from the Scottish Government is to 'only use imprisonment where necessary' and to reduce the use of short sentences. ${ }^{58}$ However, these reforms are not projected to have a significant effect on the total numbers in custody because they reduce the churn, not the overall prison population. At the long term end of the spectrum an increasing proportion of the overall population are serving life terms. This failure to engage with the politically difficult question of life imprisonment provides further insight into the limits of Scottish penal exceptionalism. Thus far, it has succeeded in 'civilising' aspects of prison practice, ${ }^{59}$ and in articulating a bold vision of its values for imprisonment, ${ }^{60}$ but it has not achieved the humane objective of reducing the overall prison population.

\section{What is to be done?}

Can life imprisonment reform, nevertheless, take advantage of the relatively progressive rhetoric of Scottish penal exceptionalism and offer a more

$5^{6} \quad$ S. McVie, loc.cit., p. 294.

57 J. Tombs and L. Piacentini, 'Prisons and Imprisonment in Scotland', in H. Croall, G. Mooney, and M. Munro, eds., Criminal Justice in Scotland (Cullompton: Willan, 2010) pp. $238-259$.

58 Scottish Government Justice Vision and Priorities Delivery Plan 2018-19 (2018). Available online: https://www.gov.scot/publications/justice-vision-priorities-delivery-plan-overview-progress-2017-18-new/pages/9/, accessed November 2019.

59 L. Brangan, 'Civilizing Imprisonment: The Limits of Scottish Penal Exceptionalism' British Journal of Criminology (2019) forthcoming doi:10.1093/bjc/azyo57.

6o K. Morrison and R. Sparks, 'Research, knowledge and criminal justice policy: the Scottish experience,' in M. Munro et al, eds., Crime, Justice and Society in Scotland. (Cullompton: Willan, 2015) pp. 42-56. 
effective way of reducing the overall prison population than has hitherto been the case?

We believe that life imprisonment reform can make a contribution to reducing incarceration, if both excessive punitiveness and excessive concern for risk are addressed, and if it concentrates on practical steps that can be explained in terms of overall Scottish penal policy. Steps that are taken to combat disproportionate punishment are easiest to identify, and many of them are also relevant to other jurisdictions seeking to reverse penal excess. ${ }^{61}$

In Scotland, a good strategy may be to begin with sentencing reform that challenges long sentences on welfare grounds and works with the judiciary in the interests of parsimony. Firstly, the imposition of life sentences for murder, or indeed any other crime, should be discretionary instead of mandatory. This would force sentencers to recognise that, while murder is always a serious crime, not all those whose conduct falls within the wide definition of murder in Scots law deserve to face a life sentence that may lead to their being detained in prison until they die there. In murder cases there should also be an option of imposing a determinate sentence, that is, fixed term of years after which release is guaranteed, rather than a life sentence.

International law has been widely interpreted as holding that mandatory death sentences are unacceptable. ${ }^{62}$ The same approach is gaining increasing traction where mandatory life imprisonment is involved. In the 2008 case of De Boucherville v. The State of Mauritius the appellant argued before the Privy Council that:

A sentence [of life imprisonment], mandatorily imposed, was subject to almost all the vices held to be inherent in the mandatory death sentence itself. It permitted no distinction to be drawn between one offence of murder and another, despite the great and well-known disparity between the culpability of different murderers, even where an intention to kill is a necessary ingredient of the offence. It allowed no account to be taken of the youth, age, vulnerability or circumstances of the individual offender. It gave the defendant no opportunity to plead for a lesser penalty before being deprived of everything worth living for, save life itself. A hearing which gave the court no scope to mitigate such a sentence was not a fair

61 For such strategies, see http://www.synergia-net.it/en/european-projects/reducingprison-population-advanced-tools-of-justice-in-europe-pre118-pe54.html, accessed November 2019.

62 R. Hood. and C. Hoyle, The Death Penalty: A Worldwide Perspective. 5th edition. (Oxford: Oxford University Press, 2015) pp. 151-154. 
hearing, and a penalty so inflicted was inhuman and degrading punishment or other treatment. ${ }^{63}$

The Privy Council accepted this argument and declared the Mauritian law unconstitutional. Other courts worldwide have followed suit in rejecting mandatory life sentences, on the grounds that they could result in disproportionately severe sentencing outcomes. ${ }^{64} \mathrm{~A}$ simple legislative change making life imprisonment a discretionary sentence for murder, could achieve the same result in Scotland.

Secondly, the Scottish Sentencing Council should be encouraged to develop guidelines for setting the maximum minimum periods of life sentences that reverse the more punitive recent jurisprudence, which has allowed punishment parts gradually to get longer. We would not recommend legislation setting starting points for the minimum terms that sentencers should consider for murders of different kinds. Where this has been done in England, it has contributed to a considerable increase in the minimum periods that prisoners convicted of murder have to serve before their release can be considered. ${ }^{65}$ Legislation should be introduced, however, to prohibit de facto whole life sentences, that is, sentences where the punishment part of life sentences is deliberately made so long that there is no chance in practice of prisoners completing them and being considered for release before they die in prison.

In law, this is important, for the ECtHR has emphasised that prisoners have to be given sentences that in practice will allow them a realistic prospect of being considered for release. This prospect is derived from the right to hope, which is fundamental to the human dignity of all persons. ${ }^{66}$ Such a right, it should be emphasised, is fully compatible with Scottish penal welfarism, which recognises that all those convicted of crimes should be given the opportunity to redeem themselves. ${ }^{67}$

63 De Bouchervillev. The State of Mauritius [2008] UKPC 37, para. 17.

64 For a recent example, which includes an overview of the international literature, see the decision of the Caribbean court of justice in August and Gabbv. The Queen, 2018 CCJ 7 AJ, 29 March 2018.

65 C. Appleton, and D. van Zyl Smit, "The Paradox of Reform: Life Imprisonment in England and Wales', in D. van Zyl Smit and C. Appleton (eds.) loc. cit. pp. 217-240.

66 Vinter v. UK, loc. cit. Concurring opinion of Judge Power-Forde.

67 The Scottish Justice Secretary recently argued: 'even if they have committed those [most serious] offences, I have to believe — and I do believe — that people have the ability to rehabilitate.' Scottish Parliament Justice Committee Official Report $11^{\text {th }}$ June, 2019. Available online: http://www.parliament.scot/parliamentarybusiness/report.aspx?r=12181\&mode= pdf., accessed November, 2019. 
A more difficult question is how best to combat an excessive concern with risk. In this regard, reformers will have to challenge the oLRs, which were not introduced with punitive concerns in mind. OLRs should be challenged on the basis that, although they may appear to be benign, as relatively short punishment parts are set for them, they are resulting in disproportionately long terms actually being served in prison. Prisoners subject to OLRS are being kept in prison for many years, after having completed the punishment parts of their sentences because, they are deemed to continue to pose a risk to society. It is important that OLR prisoners receive sufficient support during the punishment parts of their sentences to demonstrate to the Parole Board that the risk they pose has been reduced, which may be particularly challenging, given the often short punishment parts of their sentence. This, too, is a policy that is compatible with the emphasis in Scottish penal welfarism on providing prisoners with opportunities for reform.

Whether someone does pose a risk is difficult to determine, as is the harm that the person may cause to society if they released. Ronald Dworkin has emphasised that before (further) limiting someone's liberty can be considered on the basis of risk, there must be evidence of the 'vivid danger' that their future conduct may pose to the public; in other words, there must be clear evidence that the feared harm is likely to be caused. ${ }^{68}$ Von Hirsch and Ashworth have limited the type of harm that it would be appropriate to consider when keeping someone in prison for longer than their deserts would otherwise justify to 'harmful consequences of an extraordinary character'.69 These restrictive interpretations ought to be applied not only to the imposition of oLRs but also to the consideration of conditional release from all types of life imprisonment by the Parole Board. If life sentences are retained, decisions in which risk is an element will have to continue to be made. However, support should be provided to the Parole Board to grant release more frequently than occurs at present, particularly where a sentence has extended far beyond the punishment part and the persons concerned are being kept in prison effectively for what they may do in the future. It may well be that this depends in large part on those preparing and supporting the prisoner prior to consideration for release.

68 R. Dworkin, Taking Rights Seriously (London: Duckworth, 1978) p. 11. See also, A. Ashworth and L. Zedner, 'Some Dilemmas of Indeterminate Sentences: Risk and Uncertainty, Dignity and hope' in J. de Keiser, J. Roberts and J. Ryberg, Predictive Sentencing (Oxford: Hart, 2019) pp. 127-148.

69 A. van Hirsch and A. Ashworth, Proportionate Sentencing (Oxford: Oxford University Press, 2005) p. 52. 
Similarly, life prisoners who infringe their parole conditions should not be recalled automatically but only as a last resort, where a vivid danger of major harmful consequences to members of the public makes this step essential. Lesser infringements of parole conditions should be met by milder sanctions than a renewed and potentially indeterminate loss of liberty.

Finally, it is worth emphasising a further paradox surrounding life imprisonment in Scotland. If the growing numbers were merely a case of increased punitiveness that would be relatively easy to combat. However, at least some of the risk aversion that leads to long periods of imprisonment is inspired by a genuine concern for the welfare of potential victims of violent crime. Yet, imposing life imprisonment on more individuals, keeping them in prison for longer periods and effectively denying them hope of a return to a free society, means that they are being treated in an unnecessarily inhuman and degrading way. This paradox can only be addressed by demonstrating that the welfare of victims does not depend on victimising those who offend. ${ }^{70}$

The challenge for Scottish penal welfarism is to apply this insight also to persons convicted of the most serious crimes. If that is done, there is reason to believe that Scotland will cease to be the country in Europe with the highest rate of life imprisonment, allowing it to realise more fully its ambitions of penal welfarism without contradiction. If this happens, Scottish practice may become an example to other jurisdictions too, as our analysis illustrates how separate factors that converge to contribute to penal excess can be reversed to produce a more progressive and parsimonious outcome.

70 A point long argued by restorative justice advocates, see e.g. J. Shapland, et al (2007) Restorative justice: the views of victims and offenders. Ministry of Justice Research Series, $3(07)$. 